\title{
Heavy Metal Contamination in the Sediment and its Effect on the Occurrence of the Most Dominant Bivalve, Ruditapes philippinarum, on the Tidal Flats of Ariake Bay in Kumamoto Prefecture, the West Coast of Kyushu, Japan
}

\author{
Hiroaki Tsutsumi $^{1)}$, Masanori Tsukuda ${ }^{1)}$, Miho Yoshioka ${ }^{1)}$, Minoru Koga ${ }^{1)}$, Ryota Shinohara ${ }^{1)}$, \\ Yuji Nomura $^{2)}$, Kwang-Sik Choi ${ }^{3)}$, Hyeon-Seo $\mathrm{Cho}^{4)}$ and Jae-Sang Hong ${ }^{5)}$ \\ 1) Faculty of Environmental and Symbiotic Sciences, Prefectural University of Kumamoto, \\ 3-1-100 Tsukide, Kumamoto 863-8502, Japan \\ 2) Department of Biomaterials Science, Graduate School of Biomedical Science, Hiroshima University, \\ 1-2-3 Kasumi, Minami-ku, Hiroshima 734-8553, Japan \\ 3) School of Applied Marine Science, Cheju National University, Ara 1-dong, Jeju-shi, \\ Jejudo 690-756, Korea \\ 4) Ocean Environment System Program, Yosu National University, San 96-1, Dundeok-dong, Korea \\ ${ }^{5)}$ Faculty of Sciences, Inha University, Inchon 402-751, Korea
}

\begin{abstract}
A short neck clam, Ruditapes philippinarum, is one of the most dominant fauna in the benthic communities on the sand tidal flats across the Japanese coast. On the tidal flats facing to Ariake Bay in Kumamoto prefecture, more than 60,000 tons of the clam were harvested per year in the 1970 s. However, the dense populations collapsed on the tidal flats in the 1980s to 1990s. The results of the recent studies on the clam showed that its population could recover only at the sand covers on the tidal flats, which were created with the sand collected from the sea floor of the offshore areas, while the young juveniles of the clam still suffered from extremely high mortality on the sediment of the sand flats. We focussed on the concentrations of heavy metals $(\mathrm{Mn}, \mathrm{Zn}, \mathrm{Cu}, \mathrm{Cd}, \mathrm{Pb})$ in the sediments as contaminants imposing a negative impact on the physiology of the clam. The sediments on the tidal flats where the clam populations collapsed contained 1,700 to $2,900 \mu \mathrm{g} / \mathrm{g}$ of manganese, although the concentrations of the other four heavy metals of the sediments were lower than $63 \mu \mathrm{g} / \mathrm{g}$. The results of this study indicated that the dense patches of the clam were not established on the sediments containing (at least) more than $1,000 \mu \mathrm{g} / \mathrm{g}$ of manganese. It is very likely that the elevation of the concentration of manganese in the sediment is responsible for the collapse of the Ruditapes populations on the tidal flats.
\end{abstract}

Key words: Ruditapes philippinarum, clam, tidal flat, contamination, heavy metal, manganese, Ariake Bay

Received September 3, 2003: Accepted November 26, 2003 


\section{INTRODUCTION}

Ruditapes philippinarum is an edible bivalve of Veneridae, which is one of the most dominant species of the benthic communities on the sand tidal flats across the Japanese coast (Kakino 1992, Goshima 2002). It often reached high densities utilizing the extremely high primary production on the the tidal flats and play, an important roll in the nitrogen and phosphorus cycles on the sand flats of the coastal areas (Kikuchi 1993, Sasaki 1994a, 1994b, Hiwatari et al. 2002). The latest surveys on the distribution of the tidal flats in the Japanese coast (Environment Agency, 1994) reveal that 51,462 ha of tidal flats remain and approximately $20 \%$ of them are concentrated on the coast of Ariake Bay and Yatsushiro Sea in Kumamoto prefecture, the west coast of Kyushu. In these tidal flats, sandy tidal flats develop along the coast of approximately 50 linear kilometers from Kumamoto city to Arao city of Ariake Bay (approximately 7,000 ha), due to the large tidal range over $5 \mathrm{~m}$ in spring tide and the fast tidal currents. On these tidal flats, the clam, Ruditapes philippinarum, predominates in the benthic communities. Harvesting the clam on the tidal flats is one of the main fisheries on the coast of Ariake Bay in Kumamoto prefecture since the 1950s. The total amounts of the annual harvest of the clam in Kumamoto prefecture reached approximately 65,000 tons in 1977 , which was equivalent to approximately 45 $\%$ of the national clam harvest in this year (Kumamoto prefecture 1980-1994). Approximately $95 \%$ of the clam harvest in Kumamoto prefecture was brought from the sandy tidal flats along the coast of Ariake Bay. However, the dense populations of clams collapsed in the 1980s to 1990s on whole areas of the sandy flats. In 1996, the clam harvest in Kumamoto prefecture decreased to only 1,442 tons and fluctuated in the extremely small range of less than 3,000 tons until 2002 (according to the statistical information on the fishery products from Kumamoto Prefectural Federation of Fisheries Cooperative Associations).

The decrease of the harvest of Ruditapes philippinarum occurs on the sand flats not only in Kumamoto, but also in many other sand flats across Japan. Approximately 140,000 tons of the clam was harvested in 1977, but it decreased to approximately 40,000 tons in the 1990s (Sasaki 1999). The reclamation of the tidal flats is one of the main causes of the marked decrease of the clam harvest, since $40 \%$ of the tidal flats disappeared from the Japanese coast in the past five decades due to the reclamation and other reasons
(Takahashi 1994). However, the total area of the tidal flats in Kumamoto prefecture has changed very little in the past three decades. Kakino $(1992,2002)$ reviewed the possible causes of the decrease of the clam harvest excepting reclamation as follows : extremely low or high water temperature, low salinity, occurrence of hypoxic water, inflow of muddy water following heavy rain, shortage of food resources, movement of the sediment, occurrence of toxic phytoplankton, contamination of heavy metals, virus infection, and so on. To the decrease of the harvest of the clam on the tidal flats in Kumamoto, Nakahara and Nasu (2002) and Itoh (2002) suggested the possibilities of predation by shore birds, a snail (Glossaulax didyma) and a ray. However, the reasons of the marked decrease of the clam harvest on the particular tidal flats are still not clear in many cases including those of the tidal flats in Kumamoto.

Tsutsumi et al. $(2000,2002)$ studied the population dynamics of Ruditapes philippinarum on the sandy tidal flats at the river mouth of Midorikawa River in Kumamoto city since 1996. The results of this study indicated that the young juveniles of less than $5 \mathrm{~mm}$ in shell length just after settlement on the sediment of the tidal flats suffered from extremely high mortality, that such a mortality of the young juveniles was not observed on the sand covers on the tidal flats which were created with sand collected from the sea floor of the offshore areas, where the benthic communities including the clam population with densities of approximately 2,000 to 3,000 indi. $/ \mathrm{m}^{2}$ recovered, and that the high mortality of the young juveniles of the clam just after settlement on the sediment occurred again three year later on the sand covers. The environmental conditions for the clam should be equal between the areas inside and outside the sand covers except the presence of new sands collected from the sea floor of the offshore areas. Therefore, we suspect that some substances contained in the sediment on the tidal flats may cause a high mortality of the young juveniles just after settlement on the sediment.

The previous studies on Ruditapes species occurring on the tidal flats and the shallow waters near the shores reported the influences of various heavy metals contained in the sediment on the enzyme activities of Ruditapes philippinarum (Blasco \& Puppo 1999) and its closely related species in the Mediterranean sea, Ruditapes decussatus (Dellai et al. 2001), on the early development of $R$, decussatus (Beiras \& Albentosa 2003), and on the burrowing behavior of $R$. philippinarum (Shin et al. 2002). R. decussatus tends to increase the production of metallothionein or malonediadehyde when it is exposed to heavy metals 
such as Cd and Zn (Hamza-Chaffai et al. 1999, 2000, 2003; Simes et al. 2003). Moraga et al. (2002) revealed that the exposure of the clam to heavy metals influenced even the genetic diversity of the population of both of these two Ruditapes species. Morcillo and Porte (2000) showed the possibility of endoline disruption such as masculinization of $R$. decussatus caused by the exposure to ppb levels of organo-tin in the water.

We have recently studied the contaminants of the sediments on the tidal flats and their negative impact on the young juveniles of Ruditapes philippinarum to make clear the causes of the collapse of its populations on the three sandy tidal flats in Kumamoto (Midorikawa River tidal flat, Kikuchigawa River tidal flat, Arao tidal flat), Kyushu, Japan, comparing the sediment and population of the clam on a sandy tidal flat in Sonjedo in the suburbs of Inchon, Korea, where the clam still occurs densely, and the fishery harvesting the clam is popular. In our preliminary studies, we could not detect a significant level of TBT from the sediment on Midorikawa River tidal flat in Kumamoto (unpublished data), where the clam population collapsed in 1980s. In this paper, therefore, we focus on the contamination of heavy metals $(\mathrm{Mn}, \mathrm{Zn}, \mathrm{Cu}, \mathrm{Cd}, \mathrm{Pb})$ in the sediment and their negative impact on the clam population on the tidal flats. We report the concentrations of the heavy metals of the sediments and the population structures of Ruditapes on the three sandy tidal flats in Kumamoto, Japan, and one in Korea, and discuss the possibilities of the influences of heavy metals on the survival of the young juveniles of the clam just after settlement.

\section{MATERIALS AND METHODS}

\section{Study areas}

Fig. 1 shows the study areas of this study. We set five sampling stations at the four coners and the center of an area of 200 meter square (Station number is 1 to 5) on each of the three sandy tidal flats facing to Ariake Bay in Kumamoto prefecture, Midorikawa River tidal flat (Stn M; $32^{\circ} 43^{\prime} 54^{\prime \prime} \mathrm{N}, 130^{\circ} 51^{\prime} 45^{\prime \prime} \mathrm{E}$ ), Kikuchigawa River tidal flat (Stn K; $32^{\circ} 51^{\prime} 45^{\prime \prime} \mathrm{N}, 130^{\circ} 30^{\prime} 31^{\prime \prime} \mathrm{E}$ ) and Arao tidal flat (Stn A; $32^{\circ} 58^{\prime} 55^{\prime \prime} \mathrm{N}, 130^{\circ} 25^{\prime} 40^{\prime \prime} \mathrm{E}$ ), in June, 2002. On Arao tidal flat, the sand cover (approximately $100 \mathrm{~m}$ square, $50 \mathrm{~cm}$ in depth) was made to try to reestablish a habitat of the clam in the vicinity of the five sampling stations (Stn A1 to Stn A5) with the sand collected from the sea floor of offshore area called "Kaminotsu" in Ariake Bay in June 2002. We set Stn A6 inside the sand cover and Stn A7 outside the sand cover

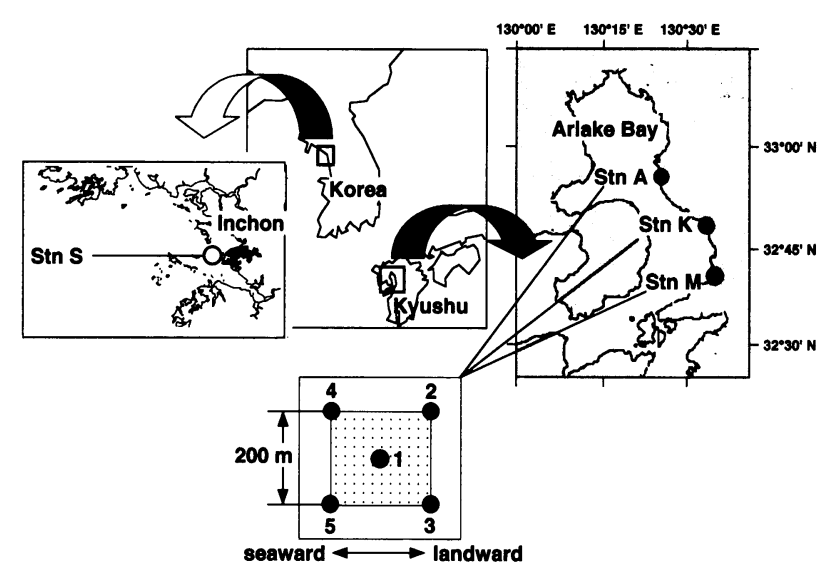

Fig. 1. Study areas of this study

in June 2003. The areas of these three tidal flats are 2,100 ha, 1,656 ha, and 1,007 ha, respectively (Japanese Environmental Agency 1994). The tidal difference reaches approximately $5 \mathrm{~m}$ on these tidal flats in spring tide.

In October, 2003, we also set a sampling station (Stn S; $37^{\circ} 14^{\prime} 34^{\prime \prime} \mathrm{N}, 126^{\circ} 32^{\prime} 21^{\prime \prime} \mathrm{E}$ ) on the sandy tidal flat at Sonjedo in the suburbs of Inchon, the northwest coast of Korea, which faces the Yellow Sea. The tidal difference of these areas reaches approximately $9 \mathrm{~m}$ in spring tide, and mega tidal flats with 68,500 ha of the total areas appear at low tide. In both of these tidal flats in Japan and Korea, harvesting clams is one of the main fisheries.

\section{Sampling methods}

We conducted the monitoring of the benthic environment and benthic communities at Arao tidal flat (Stn A1 to A5), Kikuchigawa River tidal flat (Stn K1 to K5) and Midorikawa River tidal flat (Stn M1 to M5) in the coast of Ariake Bay of Kumamoto prefecture, Kyushu, Japan, on June 12 to 14, 2002. We also carried out the same additional monitoring on the tidal flat at Stn A6 and Stn A7 on Arao tidal flat on June 12, 2003, since the sand cover (approximately $100 \mathrm{~m}$ square) was made beside the five sampling stations (Stn A1 to A5), aiming at reestablishing a suitable place for the population growth of Ruditapes in June, 2002. In Korea, we conducted the benthic monitoring on the tidal flat at Sonjedo $(\mathrm{Stn} S$ ) in the suburbs of Inchon, the northwest coast of Korea on October 23, 2002.

At each of the sampling stations, we collected the sediment up to $5 \mathrm{~cm}$ in depth with a core sample $(5 \times$ $5 \times 5 \mathrm{~cm}$ ) for particle size analysis, those up to $1 \mathrm{~cm}$ in 
depth with a syringe $(30 \mathrm{~mm}$ in diameter) from 10 different sites for the determination of heavy metals $(\mathrm{Mn}$, $\mathrm{Zn}, \mathrm{Cu}, \mathrm{Cd}, \mathrm{Pb}$ ). We also collected five sediment samples with a core sample sampler $(10 \times 10 \times 5 \mathrm{~cm})$ for the quantitative sampling of the benthic communities.

\section{Sample analysis}

The sediment for particle size analysis was sieved with standard meshes following the wet sieving method. For the determination of the concentrations of heavy metals $(\mathrm{Mn}, \mathrm{Zn}, \mathrm{Cu}, \mathrm{Cd}, \mathrm{Pb})$, the sediments were heated with nitric acid and hydrochloric acid, and the heavy metals were decomposed and extracted from the sediments. The concentrations of these heavy metals in the extracts were determined by the flame atomic absorption method (Environment Agency, Japan, 1988), using an atomic absorption spectrophotometry (Hitachi, Z-5310).

The sediment samples for the quantitative sampling of the benthic communities were sieved with a mesh of $1 \mathrm{~mm}$ opening, and the residues on the mesh were fixed with $10 \%$ formalin solution containing a dye, Rose Ben-

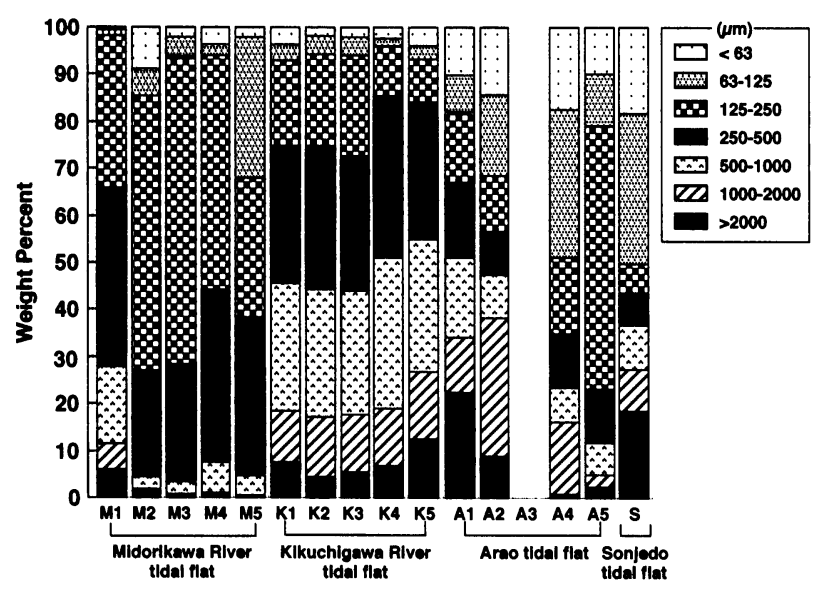

Fig. 2. Particle size composition of the sediment on the four different sandy tidal flats. gal. Under a stereoscopic microscope, benthic animals were sorted from the residues and preserved in $75 \%$ ethanol. These specimens were identified, and the number of each species was counted. After removing the water of the specimen with a blotting paper, the wet weight of each species was measured. In the case of the clam, Ruditapes philippinarum, we measured the shell length of the specimens with the shells of larger than approximately $5 \mathrm{~mm}$ in length using a a pair of calipers. The shell length of the other small specimens was determined with a microscope image analyzer (The stereoscopic microscope image of the specimen was projected on a monitor of the personal computer (Apple Macintosh IIci + Daystar Turbo040) through a CCD camera equipped with the microscope, and the length of the image was measured with image analysis software, NIH Image ver.1.55. The wet weight of each individual was calculated from the conversion equation from the shell length to the wet weight.

$$
\begin{aligned}
& \text { (wet weight }(\mathrm{g}))= \\
& \qquad 10^{(3.05 \times \log (\text { shell length }(\mathrm{mm}))-4.00)} \\
& \qquad \mathrm{r}^{2}=0.992
\end{aligned}
$$

We calculated the total wet weight of the clam population at each sampling station with the individual wet weight.

\section{RESULTS}

\section{Particle size composition of the sediment}

Table 1 and Fig. 2 indicate the particle size composition of the sediment at the sampling stations of the four tidal flats. On the tidal flat of Midorikawa River tidal flat, the sediments were moderately sorted sands (median particle size; $360 \mu \mathrm{m}$, sorting coefficient; $0.92 \phi$, cf. Gray 1981). Fine sand (125 to $250 \mu \mathrm{m})$ and medium sand (250 to $500 \mu \mathrm{m}$ ) occupied 63.1 to $90.4 \%$ in their weights. The sediments on the tidal flat of Kikuchigawa

Table 1. Mean particle size and sorting coefficient of the sediment on the four different sandy tidal flats.

\begin{tabular}{cccc}
\hline Sampling site & $\begin{array}{c}\text { Median particle } \\
\text { size }(\mu \mathrm{m})\end{array}$ & $\begin{array}{c}\text { sorting coefficient } \\
(\phi)\end{array}$ & (moderately sorted) \\
\hline Midorikawa River tidal flat & $360 \pm 99$ & $0.92 \pm 0.19$ & (poorly sorted) \\
Kikuchigawa River tidal flat & $740 \pm 90$ & $1.32 \pm 0.13$ & (poorly sorted) \\
Arao tidal flat & $480 \pm 283$ & $1.75 \pm 0.38$ & (very pooly sorted) \\
Sonjedo tidal flat & 187 & 2.43 &
\end{tabular}


River were coarser (median particle size; $740 \mu \mathrm{m}$ ) than those of Midorikawa River tidal flat. The fractions of medium sand and coarse sand (500 to $1,000 \mu \mathrm{m})$ of the sediments occupied 55.0 to $66.4 \%$ in their weights, but the mud contents of the sediments were less than $3.9 \%$, as those of the Midorikawa River tidal flat $(0.5$ to 8.9 $\%)$. The sediments on Arao tidal flat were poorly sorted (sorting coefficient: $1.75 \phi$ ). They contained 9.9 to 17.4 $\%$ of mud (silt-clay less than $63 \mu \mathrm{m}$ in diameter), while the fractions of coarse sand and further coarser ones also reached 5.1 to $17.3 \%$. The particle size composition of the sediment on the tidal flat at Sonjedo, Korea, was similar to that of the sediments on Arao tidal flat. It is very poorly sorted (sorting coefficient; $2.43 \phi$ ). The silt-clay content of the sediment was $50.3 \%$, and the median particulate size $(187 \mu \mathrm{m}$ in diameter $)$ was smallest among all of the sampling stations, while the fractions of coarse sand and further coarser ones reached $27.3 \%$.

\section{Heavy metal contamination in the sediments}

Table 2 shows the concentrations of the heavy metals $(\mathrm{Mn}, \mathrm{Zn}, \mathrm{Cu}, \mathrm{Cd}, \mathrm{Pb})$ of the sediments on the four tidal flats (the concentrations of the heavy metals on the three tidal flats in Kumamoto were represented by those at Stn M1, K1, A1, which were located at the center of the five sampling stations on each tidal flat). On all of the four tidal flats, the concentrations of manganese of the sediments were much higher than those of the other four heavy metals. In particular, its concentration reached $2,100 \mu \mathrm{g} / \mathrm{g}$ at Stn A1 on Arao tidal flat and $730 \mu \mathrm{g} / \mathrm{g}$ at Stn M1 on Midorikawa River tidal flat in Kumamoto. The concentration of the sediment at $\mathrm{Stn} S$ on the tidal flat of Sonjedo, Korea, was $300 \mu \mathrm{g} / \mathrm{g}$, only approximately one seventh of that at Stn A1. The concentration of Zinc of the sediment was highest among the four heavy metals excepting manganese, but it ranged only between 29 and $63 \mu \mathrm{g} / \mathrm{g}$. The concentrations of copper, cadmium and lead of the sediment were less than $20 \mu \mathrm{g}$ $/ \mathrm{g}$ at all of the sampling stations.

Fig. 3 shows the manganese concentrations of the

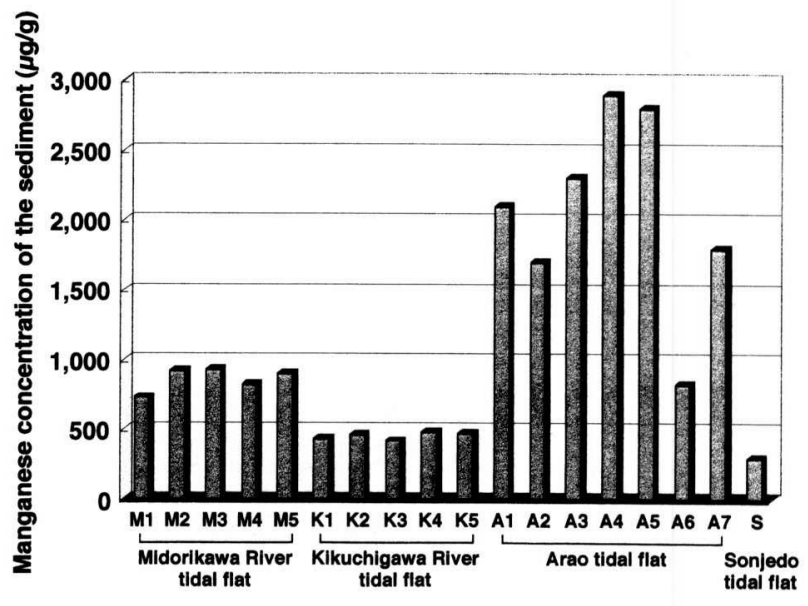

Fig. 3. The concentration of manganese in the sediment on the four different sandy tidal flats.

sediments at all of the sampling stations. On Arao tidal flat, the manganese concentrations were extremely high $(1,700$ to $2,900 \mu \mathrm{g} / \mathrm{g})$ at all of the sampling stations except Stn A6 with a newly made sand cover $(820 \mu \mathrm{g} / \mathrm{g})$. The concentration at Stn A7 outside the sand cover was $1,800 \mu \mathrm{g} / \mathrm{g}$. It indicates that the sand cover made with the sand collected from the sea floor of the offshore area in Ariake Bay created a space with distinctly lower manganese concentration (approximately $1,000 \mu \mathrm{g} / \mathrm{g}$ lower) on the tidal flat even one year after putting the sand on the tidal flat.

On Midorikawa River tidal flat, the manganese concentrations of the sediment ranged between 730 and 930 $\mu \mathrm{g} / \mathrm{g}$ at all the five sampling stations (Stn M1 to M5), which were equivalent to that at Stn A6 inside the sand cover on Arao tidal flat. On this tidal flat, the sand covers are made with the same sand collected from the offshore area in Ariake Bay since 1995. The boundaries of some of them were not clear by mixing the original sand on the tidal flat. Since all of the five sampling stations (Stn M1 to M5) were located beside the sand covers, the characteristics of the sediments seemed to be influenced by the sand dispersed from the sand covers. We also de-

Table 2. The concentrations of heavy metals $(\mathrm{Mn}, \mathrm{Zn}, \mathrm{Cu}, \mathrm{Cd}, \mathrm{Pb}$ ) in the sediments on the four different sandy tidal flats.

\begin{tabular}{|c|c|c|c|c|c|c|}
\hline Sampling site & $\mathrm{Mn}$ & $\mathrm{Zn}$ & $\mathrm{Cu}$ & $\mathrm{Cd}$ & $\mathrm{Pb}$ & $(\mu \mathrm{g} / \mathrm{g})$ \\
\hline Midorikawa River tidal flat (Stn M1) & 730 & 63 & 18 & $5>$ & $5>$ & \\
\hline Kikuchigawa River tidal flat (Stn K1) & 440 & 49 & 20 & $5>$ & $5>$ & \\
\hline Arao tidal flat (Stn A1) & 2,100 & 54 & $5>$ & $5>$ & $5>$ & \\
\hline Sonjedo tidal flat (Stn $S$ ) & 300 & 29 & 6 & $5>$ & $5>$ & \\
\hline
\end{tabular}


(a)

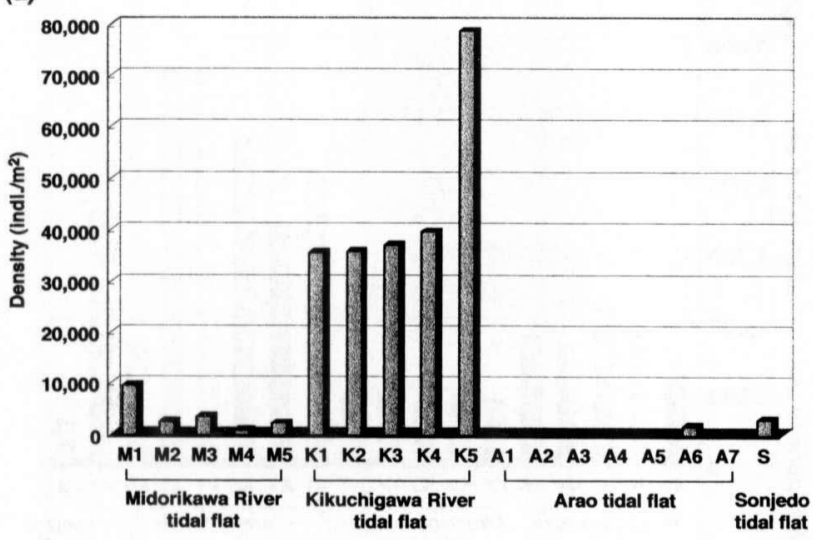

(b)

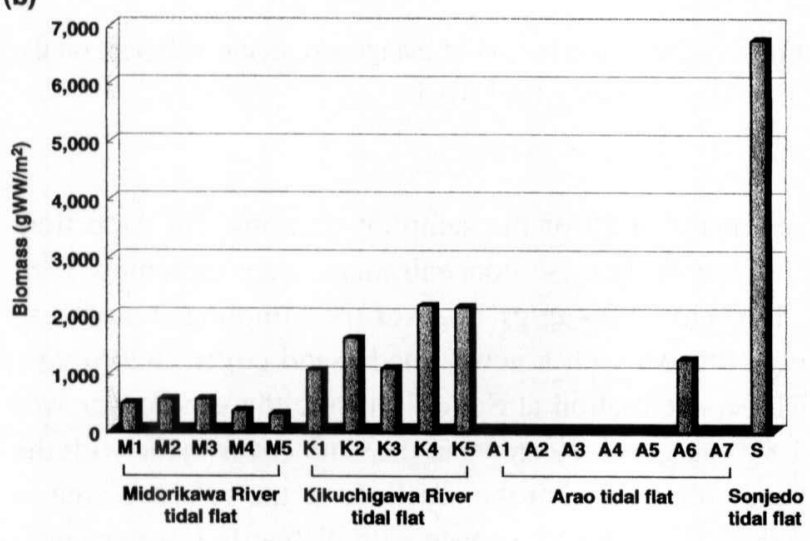

Fig. 4. (a) Densities and (b) biomass of Ruditapes philippinarum on the four different sandy tidal flats.

tected far higher concentrations of manganese (1,200 to $1,400 \mu \mathrm{g} / \mathrm{g}$ ) than the five sampling stations of this study from the places without any influence of the sand covers on this tidal flat. We will report the details of the characteristics of the sediments on Midorikawa River tidal flat elsewhere.

On Kikuchigawa River tidal flat and Sonjedo tidal flat in Korea, the manganese concentrations of the sediments were much lower than those of the other two tidal flats. They were between 420 and $480 \mu \mathrm{g} / \mathrm{g}$, and 300 $\mu \mathrm{g} / \mathrm{g}$, respectively.

\section{Density and biomass of Ruditapes population}

Fig. 4 illustrates the densities and biomass of Ruditapes philippinarum at all of the sampling stations. In terms of both densities and biomass, this species occupied at least more than $90 \%$ of those of the whole benthic communities at all of the sampling stations. Therefore, the densities and biomass of the clam represented those of the benthic communities.

Ruditapes occurred most densely at the five sampling stations (Stn K1 to K5) on Kikuchigawa River tidal flat $\left(35,520\right.$ to 78,660 indi. $\left./ \mathrm{m}^{2}\right)$. On Midorikawa River tidal flat and Sonjedo tidal flat, the densities of 880 to 9,490 indi. $/ \mathrm{m}^{2}$ and 2,810 indi. $/ \mathrm{m}^{2}$ were recorded, respectively. On Arao tidal flat, the densities were extremely low (150 to 450 indi. $/ \mathrm{m}^{2}$ ) at all of the five sampling stations (Stn A1 to A5). However, the density reached 1,600 indi. $/ \mathrm{m}^{2}$ inside the sand cover at the vicinity of these five sampling stations on the tidal flat in June 2003, when the density was still low (only 20 indi. $/ \mathrm{m}^{2}$ ) outside the sand cover.

In biomass, further distinct differences were observed among the sampling stations of the four tidal flats. The largest biomass of Ruditapes, $6,732.4 \mathrm{gWW} / \mathrm{m}^{2}$, was recorded at Stn S, Sonjedo tidal flat, Korea. Here, we collected the samples in October, 2002. Since this population seems to breed in spring or early summer as in Kumamoto, Japan, it consisted of only adults between 15 $\mathrm{mm}$ and $40 \mathrm{~mm}$ in length (Fig. 5). Therefore, the biomass was largest among all of the sampling stations, although the density was relatively low $\left(2,810\right.$ indi. $\left./ \mathrm{m}^{2}\right)$. Among the three tidal flats in Kumamoto, the biomass reached over $1 \mathrm{kgWW} / \mathrm{m}^{2}$ at the five sampling stations (Stn M1 to M5) on Kikuchigawa River tidal flat $\left(1,047.7\right.$ to $\left.2,157.4 \mathrm{gWW} / \mathrm{m}^{2}\right)$ and the sampling station outside the sand cover (Stn A6) on Arao tidal flat $\left(1,234.0 \mathrm{gWW} / \mathrm{m}^{2}\right)$. On Arao tidal flat, the biomass was extremely small $\left(0.1\right.$ to $\left.14.1 \mathrm{gWW} / \mathrm{m}^{2}\right)$ at the five sampling stations (Stn A1 to A5) and the sampling station outside the sand cover (Stn A7). At these sampling stations, the Ruditapes populations not only had low densities, but also consisted of only young juveniles with the shell length of smaller than $5 \mathrm{~mm}$ (Fig. 5). Furthermore, dead shells of smaller than $5 \mathrm{~mm}$ in shell length were also found as much as approximately $20 \%$ of the number of living individuals (Fig. 5). These facts indicate that many young juveniles soon died after settlement on Arao tidal flat.

\section{Relationship between the manganese concentration of the sediment and the Ruditapes population}

Fig. 6 indicates the relationship between the manganese concentration of the sediment and (a) the density of Ruditapes and (b) the biomass in wet weight of Ruditapes. In both of these two relationships, a clear trend approximated by a geometric function was observed. The densities of Ruditapes reached over 30,000 indi. $/ \mathrm{m}^{2}$ in the sediments with the manganese 
Kikuchigawa River tidal flat Midorikawa River tidal flat

Arao tidal flat
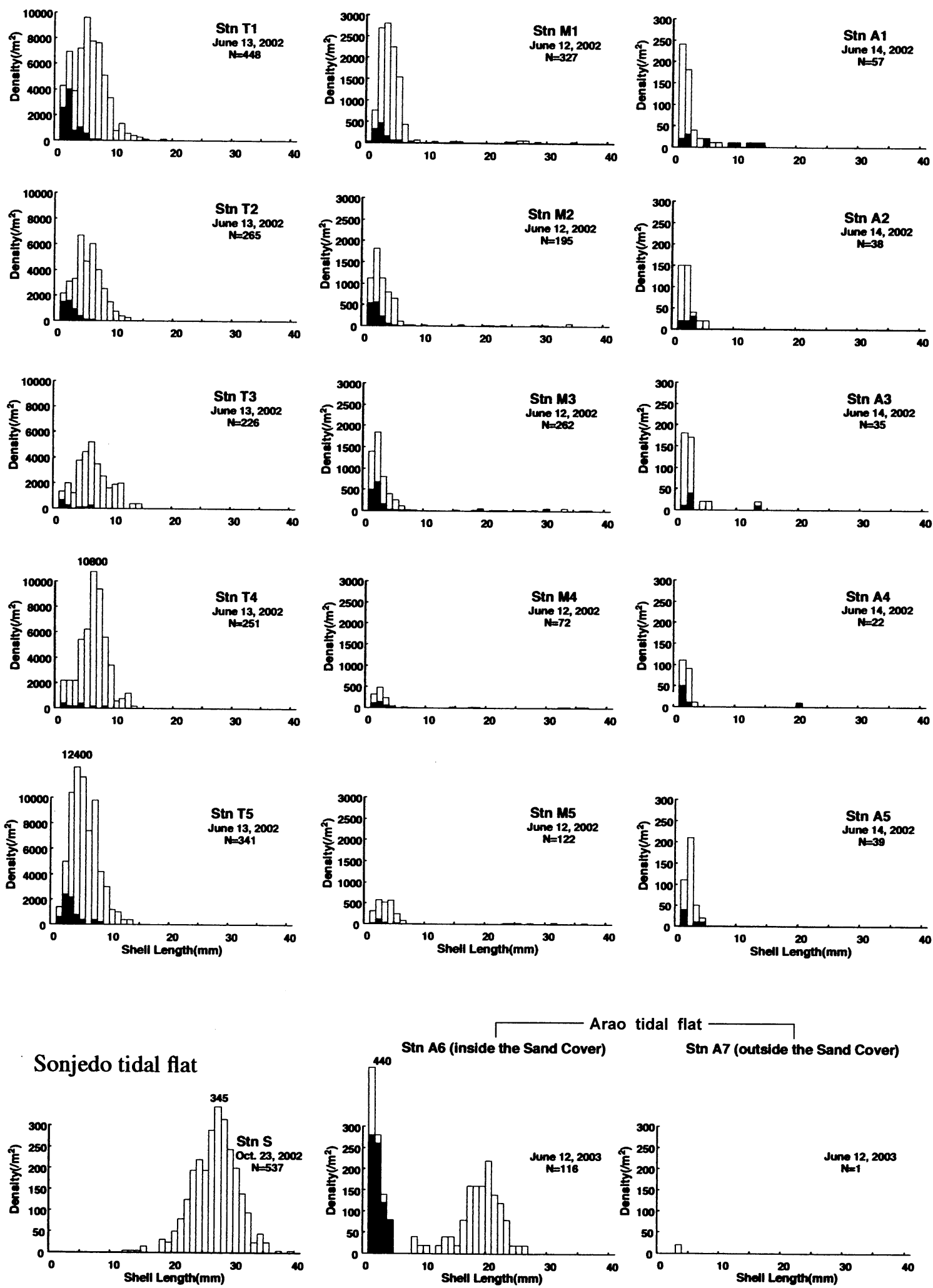

Fig. 5. Size frequency distributions of Ruditapes populations on the four different sandy tidal flats. Shaded areas indicate dead individuals. 
concentrations of lower than $500 \mu \mathrm{g} / \mathrm{g}$ except Stn $\mathrm{S}$ where the Ruditapes population consisted of only adults (Fig. 5), while the densities decreased lower than 450 indi. $/ \mathrm{m}^{2}$ at the sampling stations where the sediment contained manganese of more than $1,700 \mu \mathrm{g} / \mathrm{g}$. The biomass of Ruditapes reached $6,700 \mathrm{gWW} / \mathrm{m}^{2}$ in the sediment with the lowest concentration of manganese $(300 \mu \mathrm{g} / \mathrm{g})$ at $\mathrm{Stn} \mathrm{S}$. The biomass was also in a high range between 1,047 and $2,157 \mathrm{gWW} / \mathrm{m}^{2}$ at Stn $\mathrm{K} 1$ to $\mathrm{K} 5$, where the sediments contained 420 to $480 \mu \mathrm{g} / \mathrm{g}$ of manganese. On the other hand, only less than $14.1 \mathrm{gWW} / \mathrm{m}^{2}$ of Ruditapes was observed in the sediments with 1,700 to $2,900 \mu \mathrm{g} / \mathrm{g}$ of manganese (Stn A1 to A5 and A7). Thus, the dense patches of Ruditapes were not established in the sediments with at least more than $1,000 \mu \mathrm{g} / \mathrm{g}$ of manganese. The creation of the sand cover on the tidal flat with the one collected from the sea floor of the offshore area brought approximately $1,000 \mu \mathrm{g} / \mathrm{g}$ of decrease in the con-

(a)

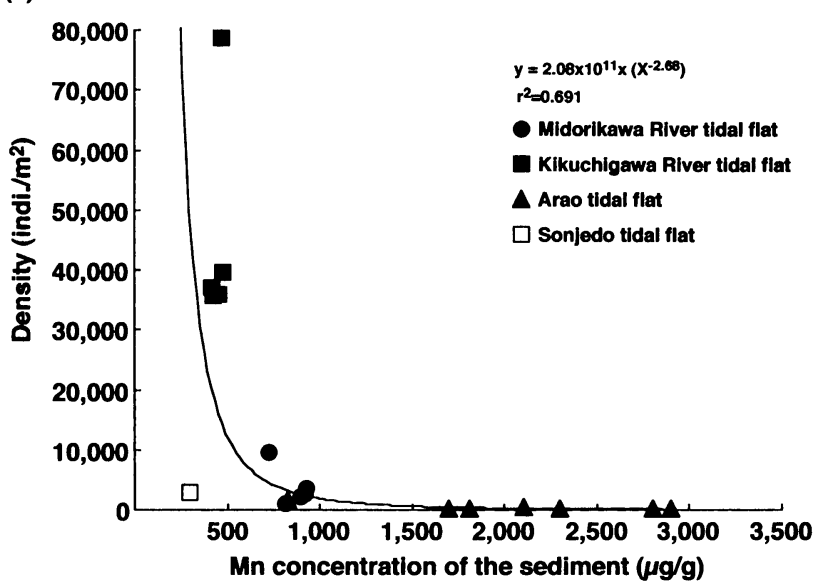

(b)

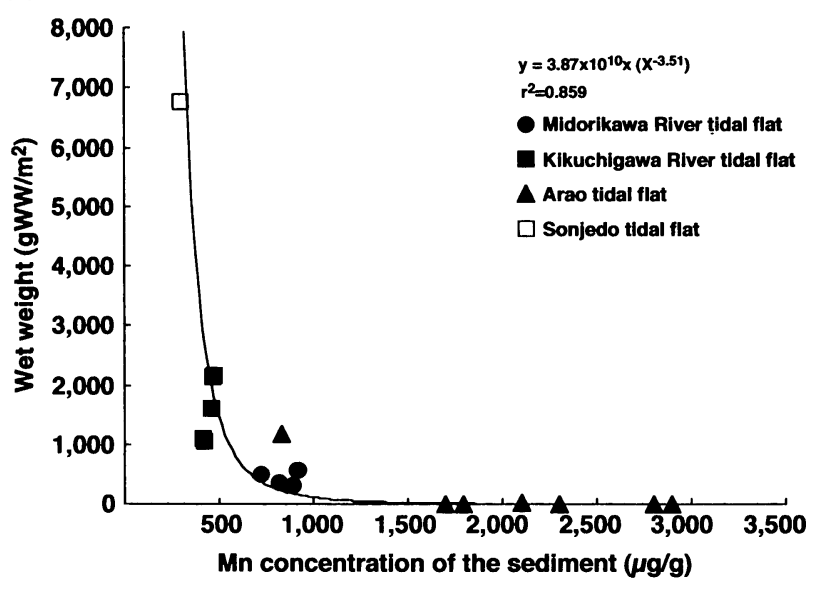

Fig. 6. The relationship between the manganese concentration of the sediment and (a) the density of Ruditapes and (b) the biomass in wet weight of Ruditapes. centration of manganese (from $1,800 \mu \mathrm{g} / \mathrm{g}$ to $820 \mu \mathrm{g} / \mathrm{g}$ even one year after the creation of the sand cover at Stn A6.

\section{DISCUSSION}

In this study, we examined the relationship between the heavy metal concentrations of the sediments and the occurrence of Ruditapes on four different sand flats in Kumamoto, Japan, and Korea. There was a clear relationship between the density and biomass of Ruditapes and only the concentration of manganese of the sediment (Fig. 6(a) and 6(b)). The density and biomass of Ruditapes reached approximately 30,000 to 78,000 indi./ $\mathrm{m}^{2}$ and 10,000 to $6,700 \mathrm{gWW} / \mathrm{m}^{2}$ in the sediments with the manganese concentration of lower than $500 \mu \mathrm{g} / \mathrm{g}$, while the density and biomass was extremely low (only lower than 450 indi. $/ \mathrm{m}^{2}$ and less than $14.1 \mathrm{gWW} / \mathrm{m}^{2}$ ) in the sediments with 1,700 to $2,900 \mu \mathrm{g} / \mathrm{g}$ of manganese.

Many recent studies have examined the toxicity and the negative impact of the various heavy metals, such as arsenic, cadmium, chrome, copper, nickel, cobalt, lead, Zinc and mercury, as the contaminants in the sediment on the physiological functions, early development and behavior of Ruditapes philippinarum and its closely related species (Ruditapes decussatus) (Blasco \& Puppo 1999; Hamza-Chaffai et al. 1999, 2000, 2003; DelValls et al. 2002; Shin et al. 2002; Beiras \& Albentosa in press; Simes et al. 2003). However, the studies focussing on the influence of the contamination of manganese in the sediment are restricted.

Manganese dioxide tended to be reduced, liquating out manganese ion, by anaerobic bacteria in the sediment, when the bottom water became hypoxic in the coastal seas in summer (Hunt \& Kelly 1988; Hall et al. 1989; Gerringa 1991; Eriksson 2000). Depledge (1985) and Barden et al. (1990a) showed that manganese ion liquated out from the sediment in hypoxic bottom waters influenced the function of the blood pigments of the benthic animals. Barden et al. (1990b) reported that the manganese ion caused serious troubles to the respiration and feeding of a lobster (Nephrops norvegicus) by adhering on its gills and bonding with blood pigments. Laboratory experiments revealed the detailed mechanisms of the negative impact of manganese ion on the physiology of the lobster (Barden et al. 1990b, 1994, 1995, 1999; Eriksson 2000). Macdonald et al. (1988) showed the negative impact of manganese on the early development of crabs.

In our following studies on manganese of the sediment, we detected three to four ppm of manganese ion 
from the interstitial water of the sediment containing approximately $2,000 \mu \mathrm{g} / \mathrm{g}$ of manganese on Arao tidal flat. It is very likely that this ppm levels of the manganese ion generated from the extremely high concentrations of manganese (mainly manganese dioxide) in the sediment is liable to cause a high mortality of young juveniles of Ruditapes with 0.5 to $1 \mathrm{~mm}$ of shell length just after the settlement on the tidal flats. In the past decade, various measures to recover the Ruditapes population have been tried on the tidal flats in Kumamoto, including three tidal flats in this study. Among them, the only effective measure is to create a sand cover on the tidal flat (Tsutsumi et al. 2002). The results on the Arao tidal flat suggest that the creation of sand flat provided the sediment free from the influence of manganese to the young juveniles of Ruditapes by decreasing the manganese concentration of the sediment to $820 \mu \mathrm{g} / \mathrm{g}$ in the surrounding sediments with manganese of $1,800 \mu \mathrm{g} / \mathrm{g}$ on the tidal flat.

Now, we are collecting more information on the contaminants of the sediment and the occurrence of the benthic animals focussing on the density and biomass of Ruditapes on the other tidal flats in Ariake Bay and the west coast of Korea, and are conducting the laboratory experiments with young juveniles of Ruditapes, the sediments with various concentrations of manganese dioxide and the sea water with various concentrations of manganese ion. From these field surveys and laboratory experiments, we are aiming to clarify the negative impact of manganese on the physiology of young juveniles of Ruditapes. We will report the results elsewhere.

Acknowledgments. The samplings on the three tidal flats in Kumamoto prefecture were conducted by obtaining the cooperation of Department of Environment and Resident Life, Kumamoto Prefectural Government, Division of Agricultural Promotion, Tamana City Office, Kawaguchi Fishery Cooperative Society, Arao City Fishery Cooperative Society, Nameishi Fishery Cooperative Society and Ohhama Fishery Cooperative Society. We would like to express our thanks to Mr. Richard Lavin for his critical reading of the manuscript. This work was supported by a Grant-in-Aid for scientific research of Japan-Korea basic scientific cooperation program and a grant for the regional research of Prefectural University of Kumamoto.

\section{REFERENCES}

Barden, S. P., Loo, L.-O., Pihl, L. and R. Rosenberg 1990a. Biological effects of eutrophication on the Swedish west coast. Ambio, 19:113-122.

Barden, S. P., Pihl, L. and R. Rosenberg 1990b. Effects of oxygen depletion on the ecology, blood physiology and fishery of the Norway lobster Nephrops norvegicus (L.). Marine Ecology Progress Series, 67: 141-155.

Barden, S. P., Depledge, M. H. and L. Hagerman 1994. Glycogen depletion and altered copper and manganese handling in Nephrops norvegicus following starvation and exposure to hypoxia. Marine Ecology Progress Series, 103: 65-72.

Barden, S. P., Eriksson, S. P. and J. M. Weeks 1995. Uptake, accumulation and regulation of manganese during experimental hypoxia and normoxia by the decapod Nephrops norvegicus (L.). Marine Pollution Bulletin, 31: 93-102.

Barden, S. P., Eriksson, S. P. and L. Gerhardt 1999. Accumulation and elimination kinetics of manganese from different tissues of the Norway lobster Nephrops norvegicus (L.). Aquatic Toxicology, 46: 127-137.

Beiras R. and M. Albentosa (in press). Inhibition of embryo development of the commercial bivalves Ruditapes decussatus and Mytilus galloprovincialis by trace metals; implications for the implementation of seawater quality criteria. Aquaculture.

Blasco J. and J. Puppo 1999. Effect of heavy metals (Cu, Cd and $\mathrm{Pb}$ ) on aspartate and alanine aminotransferase in Ruditapes philippinarum (Mollusca: Bivalvia). Comparative Biochemistry and Physiology Part C, 122: 253-263.

DelValls, T. Á., Forja, J. M. and A. Góez-Parra 2002. Seasonality of contamination, toxicity, and quality values in sediments from littoral ecosystems in the Gulf of Cáiz. Chemosphere, 46: 1033-1043.

Depledge, M. H. 1985. The influence of nutritional state on the circulatory changes in the lobster (Homarus vulgaris) during long term exposure to moderate hypoxia. Journal of experimental Biology, 73: 131-146.

Environment Agency, Japan (ed.) 1988. Monitoring methods of sediment (Teishitsu Chosahouhou to Sono Kaisetsu), Japanese Environmental Measurement \& Chemical Analysis Association, Tokyo, 175 pp.

Environment Agency, Japan 1994. The 4th basic surveys for the conservation of the natural environment. Report on the coastal fauna and environment (surveys on the tidal flat, algal bed and coral reef). Vol. 1, Tidal flat, 291pp.

Eriksson, S. P. 2000. Temporal variations of manganese in the haemolymph and tissues of the Norway lobster, Nephrops norvegicus (L.). Aquatic Toxicology, 48: 297-307.

Gerringa, L. J. A. 1991. Mobility of $\mathrm{Cu}, \mathrm{Cd}, \mathrm{Ni}, \mathrm{Pb}, \mathrm{Zn}, \mathrm{Fe}$ and $\mathrm{Mn}$ in marine sediment slurries under anaerobic conditions and at $20 \%$ air saturation. Netherland Journal of Sea Research, 27: 145-156.

Goshima, S. 2002. Crisis of Ruditapes philippinarum. Japanese Journal of Benthology, 57: 131. 
Gray, J, S, 1981. The ecology of marine sediments. Cambridge University Press, Cambridge, $185 \mathrm{pp}$.

Hall, P. O., Anderson, L. G., Rutgers van der Loeff, M. M., Sundby, B. and S. F. G. Westerlund 1989. Oxygen uptake kinetics in the benthic boundary layer. Limnology and Oceanography, 34: 734-746.

Hamza-Chaffai, A., Amiard, J. C. and R. P. Cosson 1999. Relationship between metallothioneins and metals in a natural population of the clam Ruditapes decussatus from Sfax coast: a non-linear model using Box-Cox transformation. Comparative Biochemistry and Physiology Part C, 123: 153163.

Hamza-Chaffai, A., Amiard, J. C., Pellerin, J., Joux, L. and B. Berthet 2000. The potential use of metallothionein in the clam Ruditapes decussatus as a biomarker of in situ metal exposure. Comparative Biochemistry and Physiology Part C, 127: 185-197.

Hamza-Chaffai, A., Pellerinb, J. and J. C. Amiard 2003. Health assessment of a marine bivalve Ruditapes decussatus from the Gulf of Gabe's (Tunisia). Environment International, 28: 609-617.

Hiwataria, T., Kohata, K. and A. Iijima 2002. Nitrogen budget of the bivalve Mactra veneriformis, and its significance in benthic-pelagic systems in the Sanbanse Area of Tokyo Bay. Estuarine, Coastal and Shelf Science, 55: 299-308.

Hunt, C. D. and J. R. Kelly 1988. Manganese cycling in coastal regions: response to eutrophication. Estuarine Coastal and Shelf Science, 26: 527-558.

Itoh, H. 2002. What kind of animal is the clam Ruditapes philippinarum?-Introduction to its and fishery. Japanese Journal of Benthology, 57: 134-138.

Kakino, J. 1992. Recent situation on the Japanese littleneck fisheries. Fisheries Engineering, 29: 31-39.

Kakino, J. 2002. Effects of sea water physical condition on a population of the clam Ruditapes philippinarum. Japanese Journal of Benthology 57: 158-167.

Kikuchi, T. 1993. Ecological characteristics of the tidal flat ecosystem and importance of its conservation. Japanese Journal of Ecology, 43: 223-235.

Kumamoto prefecture 1980-1994. Annual report on the clam harvest, 1978 to 1994. Department of Forestry and Fishery, Kumamoto prefecture.

Macdonald, J. M., Shields, J. D. and R. K. Zimmer-Faust 1988. Acute toxicities of eleven metals to early life-history stages of the yellow cab Cancer anthonyi. Marine Biology, 98: 201207.

Moraga, D., Mdelgi-Lasram, E., Romdhane, M. S., El Abed, A., Boutet, I., Tanguy, A. and M. Auffret 2002. Genetic responses to metal contamination in two clams: Ruditapes decussatus and Ruditapes philippinarum. Marine Environmental Research, 54: 521- 525.

Morcillo, Y. and C. Porte 2000. Evidence of endocrine disruption in clams Ruditapes decussata transplanted to a tributyltin-polluted environment. Environmental Pollution, 107: 47-52.

Nakahara, Y. and H. Nasu 2002. Report from the coastal areas of Ariake Sound, Kumamoto prefecture; the main fisheries ground for the clam Ruditapes philippinarum populations in Japan. Japanese Journal of Benthology, 57: 139-144.

Sasaki, K. 1994a. Material circulation and production in estuary and tidal flat-8, Material circulation and production in estuary and tidal flat. Aquabiology, 16: 122-128.

Sasaki, K. 1994b. Material circulation and production in estuary and tidal flat-12, The role of bivalves on the nitrogen circulation of Issiki Tidal Flat. Aquabiology, 16: 487-492.

Sasaki, K. 1999, Material circulation and production in estuary and tidal flat-30. Tidal flat and fishery resources 4 . Japanese littleneck clam of Ariake Sea. Aquabiology, 21: 162-166.

Shin, P. K. S., Ng, A: W. M. and R. Y. H. Cheung 2002. Burrowing responses of the short-neck clam Ruditapes philippinarum to sediment contaminants. Marine Pollution Bulletin, 45; 133-139.

Simes, D. C., Bebianno, M. J. and Moura, J. J. G. 2003. Isolation and characterisation of metallothionein from the clam Ruditapes decussatus. Aquatic Toxicology, 63: 307-318.

Takahashi, M. 1994. Ocean, living being and man - 8, Coastal seas and their current conditions. Aquabiology, 16: 82-87.

Tsutsumi, H., Takeguchi, T., Maruyama, A. and Y. Nakamura 2000. Seasonal fluctuations in the benthic community after the population collapse of a clam, Ruditapes philippinarum, on the Midori River tidal flats in Kumamoto. Japanese Journal of Benthology, 54: 1-8.

Tsutsumi, H., Ishizawa K., Tomishige, M., Moriyama M., Sakamoto, K. and S. Montani 2002. Population dynamics of a clam, Ruditapes philippinarum, on an artificially-created sand cover on the tidal flats at the river mouth of Midorikawa River. Japanese Journal of Benthology, 57: 177-187. 